\title{
IMPLEMENTASI ALGORITMA RIPEMD160 UNTUK MENDETEKSI KEASLIAN SERTIFIKAT TANAH
}

\author{
Joslin Nababan $^{1}$, Pristiwanto ${ }^{2}$, M.Sayuthi ${ }^{3}$ \\ Program Studi Teknologi Informatika STMIK Budi Darma,Medan, Indonesia \\ Email: ${ }^{1}$ nababanjoslin@gmail.com
}

\begin{abstract}
Abstrak
Pada era sekarang ini, sertifikat tanah sering dijadikan sebagai jaminan untuk mengajukan peminjaman uang, baik secara langsung maupun online, sehingga keamanan dari sertifikat tanah perlu ditingkatkan. Sertifikat tanah dalam bentuk digital, sangat mudah dilakukan proses manipulasi. Saat ini ada banyak perangkat lunak dapat digunakan untuk memanipulasi citra digital. Dengan kecanggihan perangkat lunak tersebut bisa membuat citra digital yang dimanipulasi sulit untuk diketahui manusia secara langsung. Proses manipulasi pada data digital juga mudah dilakukan, sehingga perlu mekanisme untuk mengetahui bahwa suatu sertifikat digital, tidak mengalami perubahan dari aslinya. Dalam kriptografi, terdapat berbagai metode yang dapat digunakan untuk mengamankan sebuah data, baik untuk menjaga kerahasiaan data, dan mendeteksi keaslian data. Salah satu teknik yang dapat digunakan adalah dengan fungsi hash yang ada dalam kriptografi. Fungsi hash merupakan fungsi satu arah yang dapat digunakan untuk mengetahui otentikasi suatu pesan. Untuk memastikan sebuah dokumen asli atau tidak, terdapat beberapa metode dengan konsep otentifikasi, serta dapat mendeteksi perubahan dokumen dari hasil manipulasi salah satunya adalah algoritma RIPEMD160. Dengan menerapkan algoritma RIPEMD160 akan memudahkan dan mempercepat untuk mendeteksi keaslian citra digital.
\end{abstract}

Kata kunci: Kriptografi, Fungsi Hash, RIPEMD160

\begin{abstract}
In this era, land certificates are often used as collateral to apply for loan money, both directly and online, so the security of land certificates needs to be improved. Land certificates in digital form, the manipulation process is very easy. Today there is a lot of software that can be used to manipulate digital images. With the sophistication of the software it can make manipulated digital images difficult for humans to know directly. The process of manipulation of digital data is also easy to do, so it needs a mechanism to know that a digital certificate, does not change from the original. In cryptography, there are various methods that can be used to secure a data, both to maintain the confidentiality of the data, and detect the authenticity of the data. One technique that can be used is the hash function in cryptography. The hash function is a one-way function that can be used to determine the authentication of a message. To ensure an original document or not, there are several methods with the concept of authentication, and can detect document changes from the results of manipulation, one of which is the RIPEMDI60 algorithm. Applying the RIPEMD160 algorithm will make it easier and faster to detect the authenticity of digital images.
\end{abstract}

Keywords: cryptography, Hash Function, RIPEMD160

\section{PENDAHULUAN}

Pada era sekarang ini, sertifikat tanah sering dijadikan sebagai jaminan untuk mengajukan peminjaman uang, baik secara langsung maupun online, hal ini merupakan salah satu hal yang menyebabkan mudahnya seseorang dalam memanipulasi sertifikat tanah, sehingga keamanan dari sertifikat tanah perlu ditingkatkan. Sertifikat tanah dalam bentuk digital, sangat mudah dilakukan proses manipulasi, baik dalam hal mengubah isi surat tanah sipemilik maupun dalam hal penggandaan sertifikat tanah. Saat ini ada banyak perangkat lunak dapat digunakan untuk memanipulasi citra digital. Dengan kecanggihan perangkat lunak tersebut bisa membuat citra digital yang dimanipulasi sulit untuk diketahui manusia secara langsung. Sertifikat ganda menimbulkan ketidakpastian hukum, apabila sertifikat itu digunakan untuk kepentingan tertentu dapat menimbulkan ketidak jelasan hak dan kewajiban bagi pemegangnya dan berpotensi merugikan berbagai pihak, serta berpotensi memunculkan sengketa hukum diantara pihak yang terkait. Proses manipulasi pada data digital juga mudah dilakukan, sehingga perlu mekanisme untuk mengetahui bahwa suatu sertifikat digital, tidak mengalami perubahan dari aslinya[1].

Kriptografi merupakan salah satu metode pengamanan data yang dapat digunakan untuk menjaga kerahasiaan data, keaslian data, serta keaslian pengiriman. Metode ini bertujuan agar informasi yang bersifat rahasia yang dikirim melalui telekomuikasi umum tidak dapat diketahui atau dimanfaatkan orang yang tidak berkepentingan atau yang tidak berhak. Dalam kriptografi, terdapat berbagai metode yang dapat digunakan untuk mengamankan sebuah data, baik untuk menjaga kerahasiaan data, dan mendeteksi keaslian data. Untuk memastikan sebuah dokumen asli atau tidak, terdapat beberapa metode dengan konsep otentifikasi, serta dapat mendeteksi perubahan dokumen dari hasil manipulasi salah satunya adalah algoritma RIPEMD160. Algoritma RIPEMD160 merupakan variasi dari algoritma MD4 dan peningkatan dari algoritma RIPEMD128. Algoritma RIPEMD160 juga merupakan suatu fungsi hash kriptografi yang cepat, dan dirancang untuk implementasi pada perangkat lunak dengan arsitektur 32- bit. RIPEMD160 menghasilkan 160 bit. Hal ini dimaksudkan untuk menyediakan level yang lebih tinggi untuk 10 tahun yang akan datang[2].

\section{TEORITIS}

\subsection{Kriptografi}


Kriptografi (cryptography) berasal dari bahasa Yunani: "cryptos" artinya "secret" (rahasia), sedangkan "graphein" artinya "writing" (tulisan). Jadi, kriptografi berarti "secret writing" (tulisan rahasia)[3]. Kriptografi pada awalnya dijabarkan sebagai ilmu yang mempelajari bagaimana menyembunyikan pesan, namun pada pengertian modern kriptografi berarti ilmu yang bersandarkan pada teknik matematika untuk berurusan dengan keamanan informasi seperti kerahasiaan, keutuhan data dan otentifikasi entitas[4]. Kriptografi juga dapat diartikan sebagai ilmu yang mempelajari tentang teknik matematika yang berhubungan dengan aspek keamanan informasi seperti tingkat keyakinan, integritas data, autentifikasi entitas dan autentifikasi keaslian data[5].

\subsection{Fungsi Hash}

Fungsi hash memiliki kemiripan dalam struktur iterasi. Struktur tersebut berlandaskan pada kaidah-kaidah pada fungsi kompresi. Dengan kata lain, komputasi untuk menghasilkan fungsi hash sangat bergantung pada pesan input yang diberikan (message depend) yang biasa disebut dengan variabel berantai (chaining variable). Pada permulaan proses hashing, chaining variable tersebut diinisialisasi dengan suatu nilai tertentu yang sifatnya tetap. Hal ini merupakan salah satu dari spesifikasi algoritma fungsi hash[3].

Fungsi kompresi digunakan untuk mengubah atau update nilai-nilai yang terdapat chaining variable dengan menggunakan cara atau algoritma yang cukup rumit. Proses ini berlanjut secara rekursif dengan chaining variable selalu di-update terus menerus untuk setiap bagian pada pesan tersebut, hingga semua pesan telah digunakan. Nilai akhir dari chaining variabel akan menjadi nilai hash yang berkorespondensi dengan pesan tersebut. Fungsi hash yang dipakai alam kriptografi harus memenuhi beberapa syarat sehingga dapat dianggap aman, yaitu preimage, second preimage dan collision[6].

1. Preimage

Kriteria keamanan dengan syarat Preimage yaitu ketahanan terhadap serangan, dimana fungsi hash diharuskan bersifat satu arah.

2. Second Preimage

Sebuah fungsi hash untuk sistem kriptografi harus tahan terhadap serangan second preimage atau engan kata lain sulit bagi penyerang untuk menyelesaikan persoalan second preimage.

3. Collision

Persoalan collision hampir mirip dengan persoalan second preimage hanya saja persoalan collision penyerang hanya diberikan fungsi hash lalu penyerang berusaha menemukan sepasang pesan.

\subsection{Algoritma RIPEMD160}

Algoritme RIPEMD-160 (Race Integrity Primitives Evaluation Message Digest-160), dirancang oleh Bart Preneel, Antoon Bosselaers dan Hans Dobbertin pada tahun 1996, merupakan fungsi hash kriptografi yang cepat yang dibuat untuk diimplementasikan pada software yang dijalankan pada mesin berarsitektur 32-bit. RIPEMD-160 adalah salah satu contoh algoritma hash yang sering juga disebut dengan nama fungsi pembanding, fungsi penyusutan, intisari pesan, sidik jari, message integrity check (MIC) atau pemeriksa keutuhan pesan dan manipulation detection code (MDC) atau pendeteksi penyelewengan kode[3].

RIPEMD-160 adalah suatu fungsi hash kriptografi yang dirancang untuk implementasi pada perangkat lunak dengan arsitektur 32 bit. Desain utama dari fungsi hash ini ada dua proses komputasional yang berbeda dan saling independen, dimana hasil dari kedua proses ini akan digabungkan pada akhir perhitungan dengan sebuah fungsi kompresi. Sesuai dengan namanya RIPEMD-160 menghasilkan 160 bit. Hal ini dimaksudkan untuk menyediakan level sekuritas yang lebih tinggi untuk 10 tahun yang akan datang. Sama halnya dengan varian MD4 lainnya, RIPEMD-160 beroperasi pada prosesor 32-bit. Operasi dasar pada fungsi ini adalah sebagai berikut[3]:

1. Rotasi kiri (left-rotation atau left-spin) dari pesan masukan;

2. $\quad$ Operasi bitwise Boolean AND $(\Lambda), N O T(\sim), O R(\vee)$, exclusive-OR $(\bigoplus)$;

3. Penambahan dua buah string sepanjang modulo $2^{32}$ pada nilai hash (addition modulo).

Dibawah ini adalah deskripsi langkah-langkah proses perhitungan nilai hash pada algoritma RIPEMD-160

[2]:

1. Definisi fungsi, permutasi dan inisialisasi buffer.

Sebelum proses perhitungan, terlebih dahuIu didefinikan fungsi-fungsi dan permutasi yang akan digunakan pada proses kompresi. Definisi kelima fungsi tersebut adalah :

1. $f 1(x, y, z)=(x \oplus y \oplus z)$

2. $f 2(x, y, z)=[(x \wedge y) \vee(\sim x \wedge z)]$

3. $f 3(x, y, z)=[(x \vee \sim y) \oplus z]$

4. $f 4(x, y, z)=[(x \wedge z) \vee(y \wedge \sim z)]$

5. $f 5(x, y, z)=[x \oplus(y \vee \sim z)]$ 
Kemudian disiapkan juga suatu vektor awal, yaitu buffer $\left(\mathrm{H}_{0}, \mathrm{H}_{1}, \mathrm{H}_{2}, \mathrm{H}_{3}, \mathrm{H}_{4}\right)$, yang masing-masing nilainya dalam notasi heksadesimal adalah:

$\mathrm{H}_{0}: 67452301 \mathrm{x}$;

$\mathrm{H}_{1}$ : EFCDAB89x

$\mathrm{H}_{2}$ : 98BADCFEx;

$\mathrm{H}_{3}: 10325476 \mathrm{x}$;

$\mathrm{H}_{4}$ : C3D2EIFOx

Selain lima buffer yang digunakan sebagai penyimpan nilai awal, dalam algortima RIPEMD160 ini digunakan juga 10 buffer untuk menyimpan nilai sementara selama proses kompresi.

2. Padding pesan

Pesan diisi sehingga panjangnya kongruen dengan 448, modulus 512. Padding 1 bit ditambahkan di akhir pesan, diikuti oleh banyaknya nol yang diperlukan sehingga panjang bit sama dengan 448 modulus 512 .

3. Panjang Append

Proses padding dilakukan dengan cara menambahkan satu buah bit "1" diikuti k buah bit "0" diikuti dengan 64bit integer, yang merupakan representasi biner dari panjang pesan asli, pada akhir pesan asli dirnana 32 least significant bit diletakkan didepan 32-most significant bit sehingga panjangnya merupakan kelipatan 512.

4. Proses Kompresi

Bagian yang merupakan inti dari proses algoritma RIPEMD-16() ini, terdiri dari dua buah rantai fungsi, masingmasing terdiri dari 5 round, dimana setiap round-nya terdiri dari 16 operasi, yang dirangkai secara paralel. Langkah-langkahnya adalah:

a. Pendefinisian fungsi $\mathrm{F}$ dan $\mathrm{F}^{\prime}$, konstanta $\mathrm{K}$ dan $\mathrm{K}$ ' untuk masing-masing round.

b. Pada setiap blok $\mathrm{X}_{1}, \mathrm{X}_{2}, \ldots \mathrm{X}_{\mathrm{n}}$ lakukan langkah-langkah sebagai berikut:

1. Bagi Xi ke dalam 16 subblok 32 bit yaitu $X[k], 0 \leq \mathrm{k} \leq 15$, menggunakan metode endian kecil, dengan mengubah susunan urutan byte, dimana paling kanan dijadikan high order diikuti oleh byte selanjutnya sampai dengan byte paling kiri dijadikan low order.

2. Set $A=A^{\prime}=H_{0}$,

$\mathrm{B}=\mathrm{B}^{\prime}=\mathrm{H}_{1}$,

$\mathrm{C}=\mathrm{C}^{\prime}=\mathrm{H}_{2}$,

$\mathrm{D}=\mathrm{D}^{\prime}=\mathrm{H}_{3}$,

$\mathrm{E}=\mathrm{E}^{\prime}=\mathrm{H}_{4}$

3. Kemudian, lakukan semua operasi yang ada pada kedua rangkaian rantai paralelnya. Setiap operasinya berupa fungsi (a, b, c, d, e, X[i], s], yang mendefinisikan operasi :

$\mathrm{T} \longleftarrow((\mathrm{A} \boxplus f(j, \mathrm{~B}, \mathrm{C}, \mathrm{D}) \boxplus \mathrm{X} i[r(j)] \boxplus \mathrm{K}(\mathrm{j}) \ll s(j)) \boxplus \mathrm{E} ;$

$(\mathrm{A} \longleftarrow \mathrm{E}) ;(\mathrm{E} \longleftarrow \mathrm{D}) ;(\mathrm{D} \longleftarrow \mathrm{C}<<10) ;(\mathrm{C} \leftarrow \mathrm{B}) ;(\mathrm{B} \leftarrow \mathrm{T}) ;$

$\mathrm{T}^{\prime} \longleftarrow\left(\left(\mathrm{A}^{\prime} \boxplus f\left(79-j, \mathrm{~B}^{\prime}, \mathrm{C}^{\prime}, \mathrm{D}^{\prime}\right) \boxplus \mathrm{X} i[r(j)] \boxplus \mathrm{K}^{\prime}(\mathrm{j})<<s^{\prime}(j)\right) \boxplus \mathrm{E}^{\prime} ;\right.$

$\left(\mathrm{A}^{\prime} \longleftarrow \mathrm{E}^{\prime}\right) ;\left(\mathrm{E}^{\prime} \longleftarrow \mathrm{D}^{\prime}\right) ;\left(\mathrm{D}^{\prime} \longleftarrow \mathrm{C}^{\prime}<<10\right) ;\left(\mathrm{C}^{\prime} \longleftarrow \mathrm{B}^{\prime}\right) ;\left(\mathrm{B}^{\prime} \longleftarrow \mathrm{T}^{\prime}\right)$;

Dimana $\mathrm{f}$ adalah nama fungsi, buffer $\mathrm{a}, \mathrm{b}, \mathrm{c}, \mathrm{d}$ dan e adalah buffer untuk menampung nilai sementara, $\mathrm{X}$ [i] adalah notasi dari 16 subblok dan $k$ adalah konstanta yang digunakan untuk masing-masing round, sedangkan $<<s$ adalah operasi pergeseran bit ke kiri sebanyak s bit, serta simbol $\boxplus$ dinotasikan sebagai addition modulo (add mod) $2^{32}$.

Untuk penyelesaian akhir, penjumlahan seperti berikut:

$\mathrm{t}=h 1+\mathrm{C}+D^{\prime}$

$h 1=h 2+\mathrm{D}+\mathrm{E}$

$h 2=h 3+E+A$,

$h 3=h 4+\mathrm{A}+B^{\prime}$

$h 4=h 0+\mathrm{B}+\mathrm{C}^{\prime}$

$h O=t$

c. Output

Output didapat setelah semua blok $\mathrm{X}_{0}, \mathrm{X}_{1}, \ldots \mathrm{X}_{\mathrm{n}}$ selesai diproses. Nilai hash-nya merupakan penggabungan nilai kelima buffer Ho, HI, H2, H3 dan H4 setelah sebelumnya masing-masing buffer Hi dikonversikan menjadi string 4-bytes dengan menggunakan metode konversi endian kecil.

\subsection{Citra Digital}

Nilai suatu pixel memiliki nilai dalam rentang tertentu, dari nilai minimum sampai nilai maksimum. Jangkauan yang digunakan berbeda-beda tergantung dari jenis warnanya. Namun secara umum jangkauanya adalah 0-255. Citra dengan penggambaran seperti ini digolongkan kedalam citra integer. Berikut ini jenis jenis citra berdasarkan nilai pixelnya[7]

\section{ANALISA DAN PEMBAHASAN}

Page $\mid 282$ 


\subsection{Analisa}

Pada bagian analisa ini dipersiapkan file citra sertifikat tanah dengan format JPEG dan resolusi 902 x 1280 pixel. File tersebut akan dideteksi keasliannya dengan menggunakan algoritma RIPEMD160 dan akan menghasilkan kode hash. Pada proses pengambilan nilai hash dilakukan terhadap data binary dari nilai warna RGB file dalam matriks citra. Identitas file yang diberikan pada file citra menandakan bahwa file citra akan diketahui mengalami perubahan ataupun tidak. Persiapan yang dilakukan selain hasil scan citra sertifikat tanah digunakan aplikasi Matlab yang berguna untuk mengambil nilai piksel warna RGB dan kemudian dilakukan proses encoding secara RIPEMD160 pada RGB scan file citra sertifikat tanah tersebut. Kode hash yang digunakan untuk mendeteksi keaslian sertifikat tanah kemudian akan disimpan dalam sebuah metadata yang berisi informasi tentang file tersebut. Metadata dari file berisi tentang resolusi citra, dimensi citra serta ukuran dari citra tersebut.

Adapun model tahap pengamanan citra sertifikat tanah menggunakan metode RIPEMD160 disajikan pada gambar di bawah ini:

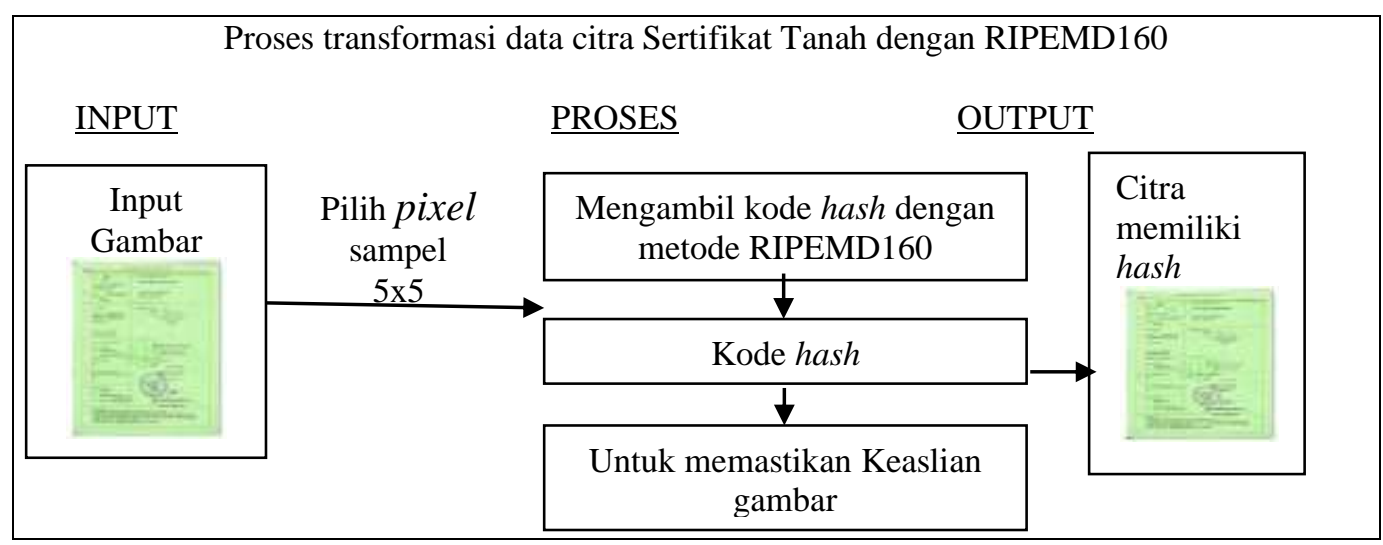

Gambar 1. alur analisa penelitian

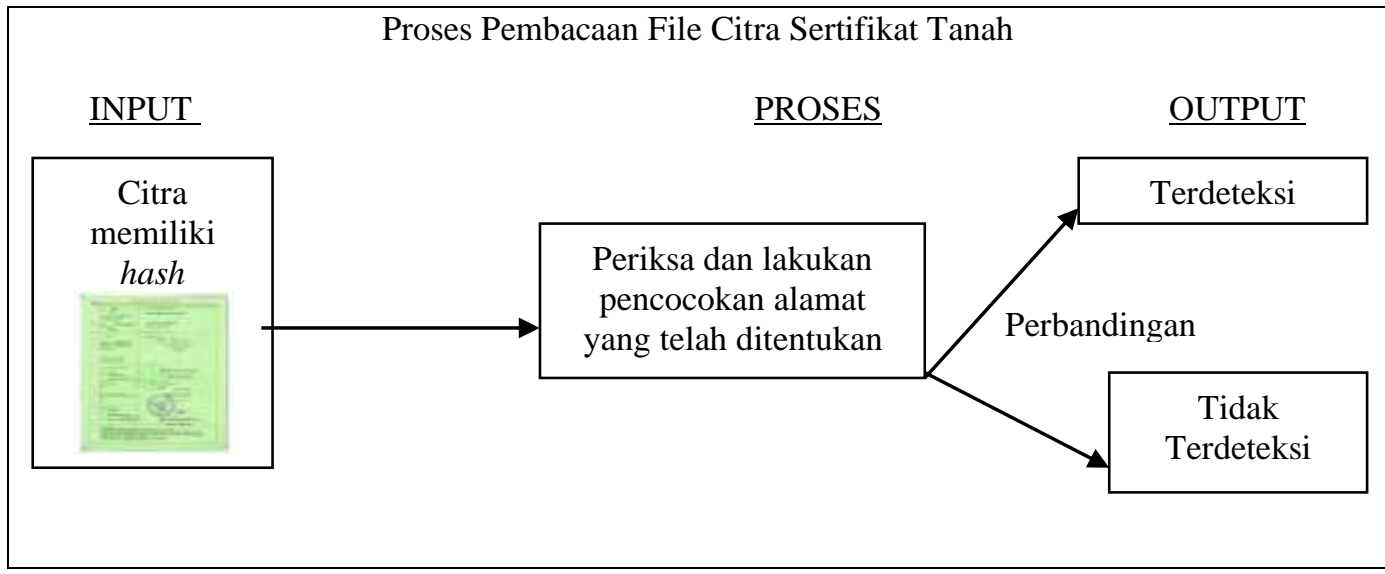

Gambar 2. Alur pembacaan deteksi file citra sertifikat tanah

Pada penelitian skripsi ini, terdapat dua proses yang akan dikerjakan. Proses-proses tersebut digambarkan seperti pada gambar 1 dan 2. Pada gambar 1 menjelaskan proses pengambilan nilai hash melalui pixel RGB dengan metode RIPEMD160, sedangkan pada gambar 2 melakukan pemeriksaan file citra sertifikat tanah awal terhadap file citra dengan perubahan metadata dari file citra tersebut dengan ketentuan output asli atau tidak asli.

Sampel citra yang diuji dalam analisa adalah file citra dari sertifikat tanah dengan format jpeg. File citra tersebut memiliki resolusi 902 x 1280 pixel. Berikut ini adalah file citra digital sertifikat tanah yang digunakan.
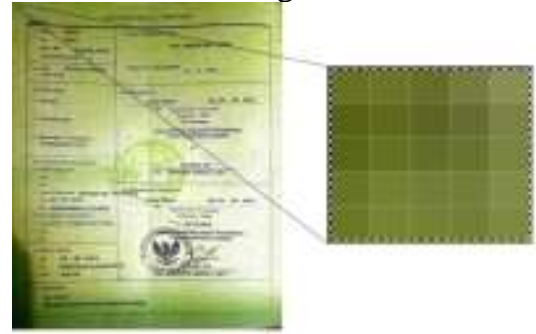

Gambar 3. File citra sertifikat tanah 


\subsection{Pembahasan}

Proses perhitungan manual pada citra sertifikat tanah menggunakan algoritma hash RIPEMD160, dengan ekstensi jpeg, resolusi 902 x 1280 pixel. Untuk memudahkan proses analisa maka diambil sampel dari hasil citra sertifikat tanah berukuran 5 x 5 pixel, dimana nilai pixel tersebut diambil menggunakan aplikasi Matlab. Nilai pixel citra sertifikat tanah (sampel) dapat dilihat pada tabel berikut:

Tabel 1. nilai RGB dari citra sertifikat tanah

\begin{tabular}{ccccc}
\hline 47 & 87 & 84 & 99 & 123 \\
68 & 77 & 75 & 85 & 107 \\
170 & 83 & 82 & 88 & 106 \\
84 & 99 & 98 & 100 & 113 \\
87 & 101 & 101 & 98 & 109 \\
\hline
\end{tabular}

\subsubsection{Penerapan Algoritma RIPEMD160}

Berikut ini langkah-langkah penerapan algoritma RIPEMD160 untuk mendeteksi keaslian sertifikat tanah, dimana sebelumnya terlebih dahulu dilakukan pengubahan nilai pixel dari citra sertifikat tanah menjadi bilangan biner.

Tabel 2. nilai pixel RGB dalam biner

\begin{tabular}{lllll}
\hline 00101111 & 01010111 & 01010100 & 01100011 & 01111011 \\
01000100 & 01001101 & 01001011 & 01010101 & 01101011 \\
10101010 & 01010011 & 01010010 & 01011000 & 01101010 \\
01010100 & 01100011 & 01100010 & 01100100 & 01110001 \\
01010111 & 01100101 & 01100101 & 01100010 & 01101101 \\
\hline
\end{tabular}

1. Penambahan padding bit

Dari tabel nilai pixel RGB dalam biner diketahui bahwa panjang $l=200$ bit. Proses berikutnya adalah dengan menambahkan padding bit 1 dan sisanya 0 sejumlah $k$, dengan persamaan sebagai berikut :

$k=l+1 \equiv 448 \bmod 512$

$k=200+1 \equiv 448 \bmod 512$

$k=201 \equiv 448 \bmod 512$

$k=448-201$

$k=247$

2. Penambahan panjang append

Penambahan panjang append dilakukan dengan penambahan panjang pesan sebanyak 64 bit di akhir. Panjang pesan adalah 200 bit sehingga ditambahkan panjang append

3. Parsing pesan (pengelompokan pesan)

Pada tahap parsing pesan, bagi X ke dalam 16 subblok 32 bit yaitu $\mathrm{X}(0) \ldots \mathrm{X}(15)$.

Tabel 3. Parsing Pesan

\begin{tabular}{lc} 
& Tabel 3. Parsing Pesan \\
\hline $\mathrm{X}_{0}$ & 00101111010101110101010001100011 \\
$\mathrm{X}_{1}$ & 01111011010001000100110101001011 \\
$\mathrm{X}_{2}$ & 01010101011010111010101001010011 \\
$\mathrm{X}_{3}$ & 01010010010110000110101001010100 \\
$\mathrm{X}_{4}$ & 01100011011000100110010001110001 \\
$\mathrm{X}_{5}$ & 01010111011001010110010101100010 \\
$\mathrm{X}_{6}$ & 01101101100000000000000000000000 \\
$\mathrm{X}_{7}$ & 00000000000000000000000000000000 \\
$\mathrm{X}_{8}$ & 00000000000000000000000000000000 \\
$\mathrm{X}_{9}$ & 00000000000000000000000000000000 \\
$\mathrm{X}_{10}$ & 00000000000000000000000000000000 \\
$\mathrm{X}_{11}$ & 00000000000000000000000000000000 \\
$\mathrm{X}_{12}$ & 00000000000000000000000000000000 \\
$\mathrm{X}_{13}$ & 00000000000000000000000000000000 \\
$\mathrm{X}_{14}$ & 00000000000000000000000000000000 \\
$\mathrm{X}_{15}$ & 00000000000000000000000011001000 \\
\hline
\end{tabular}

4. Inisialisasi nilai hash 
Setelah proses parsing pesan maka langkah selanjutnya adalah inisialisasi nilai hash di mana nilai ini merupakan sebuah ketentuan yaitu :
$\mathrm{H}_{0}: 67452301 \mathrm{x}$
$\mathrm{H}_{1}:$ EFCDAB89x
$\mathrm{H}_{2}:$ :98BADCFEx;
$\mathrm{H}_{3}$ : 10325476x;
$\mathrm{H}_{4}$ : C3D2EIFOx

5. Proses Kompresi

Proses kompresi merupakan inti dari proses algoritma RIPEMD160, terdiri dari dua buah rantai fungsi. Diagram fungsi kompresi adalah sebagai berikut:

1. Notasi X (subblok)

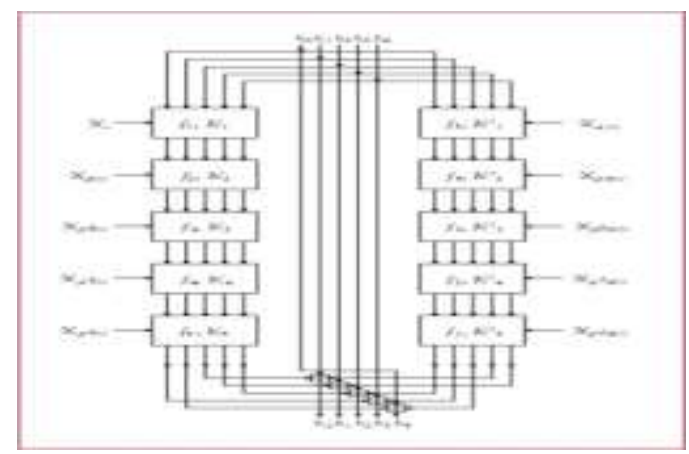

Gambar 4. Tahapan fungsi Kompresi

Pemilihan subblok ditentukan dengan tabel fungsi permutasi $r$

Tabel 4. fungsi permutasi $\mathrm{r}$

\begin{tabular}{cc}
\hline \multicolumn{2}{c}{ Tabel 4. fungsi permutasi r } \\
\hline$r(j)$ & $=7,4,13,1,10,6,15,3,12,0,9,5,2,14,11,8$ \\
$r(16 . .31)$ & $=3,10,14,4,9,15,8,1,2,7,0,6,13,11,5,12$ \\
$r(32 . .47)$ & $=1,9,11,10,0,8,12,4,13,3,7,15,14,5,6,2$ \\
$r(48 . .63)$ & $=4,0,5,9,7,12,2,10,14,1,3,8,11,6,15,13$ \\
$r(64 . .79)$ & $=5,14,7,0,9,2,11,4,13,6,15,8,1,10,3,12$ \\
$r(0 . .15)$ & $=6,11,3,7,0,13,5,10,14,15,8,12,4,9,1,2$ \\
$r(16 . .31)$ & $=15,5,1,3,7,14,6,9,11,8,12,2,10,0,4,13$ \\
$r(32 . .47)$ & $=8,6,4,1,3,11,15,0,5,12,2,13,9,7,10,14$ \\
$r(48 . .63)$ & $=12,15,10,4,1,5,8,7,6,2,13,14,0,3,9,11$ \\
$r(64 . .79)$ & Tabel 5. pergeseran jumlah rotasi \\
\hline & $=11,14,15,12,5,8,7,9,11,13,14,15,6,7,9,8$ \\
\hline$s(0 . .15)$ & $=7,6,8,13,11,9,7,15,7,12,15,9,11,7,13,12$ \\
& $=11,13,6,7,14,9,13,15,14,8,13,6,5,12,7,5$ \\
$s(16 . .31)$ & $=11,12,14,15,14,15,9,8,9,14,5,6,8,6,5,12$ \\
$s(32 . .47)$ & $=9,15,5,11,6,8,13,12,5,12,13,14,11,8,5,6$ \\
$s(48 . .63)$ & $=8,9,9,11,13,15,15,5,7,7,8,11,14,14,12,6$ \\
$s(64 . .79)$ & $=9,13,15,7,12,8,9,11,7,7,12,7,6,15,13,11$ \\
$s(0 . .15)$ & $=9,7,15,11,8,6,6,14,12,13,5,14,13,13,7,5$ \\
$s(16 . .31)$ & $=15,5,8,11,14,14,6,14,6,9,12,9,12,5,15,8$ \\
$s(32 . .47)$ & $=8,5,12,9,12,5,14,6,8,13,6,5,15,13,11,11$ \\
$s(48 . .63)$ &
\end{tabular}

2. Notasi Fungsi

Fungsi f menyatakan fungsi bolean yang menerima tiga input kata 32 bit. Defenisi fungsi f adalah:

$$
\begin{aligned}
\mathrm{f}(\mathrm{j}, \mathrm{x}, \mathrm{y}, \mathrm{z}) & =\mathrm{x} \oplus \mathrm{y} \oplus \mathrm{z} \\
\mathrm{f}(\mathrm{j}, \mathrm{x}, \mathrm{y}, \mathrm{z}) & =(\mathrm{x} \wedge \mathrm{y}) \vee(\sim \mathrm{x} \wedge \mathrm{z}) \\
\mathrm{f}(\mathrm{j}, \mathrm{x}, \mathrm{y}, \mathrm{z}) & =(\mathrm{x} \vee \sim \mathrm{y}) \bigoplus \mathrm{z} \\
\mathrm{f}(\mathrm{j}, \mathrm{x}, \mathrm{y}, \mathrm{z}) & =(\mathrm{x} \wedge \mathrm{z}) \vee(\mathrm{y} \wedge \sim \mathrm{z}) \\
\mathrm{f}(\mathrm{j}, \mathrm{x}, \mathrm{y}, \mathrm{z}) & =\mathrm{x} \oplus(\mathrm{y} \vee \mathrm{z})
\end{aligned}
$$

Dimana urutan penggunaan fungsi-fungsi tersebut adalah sebagai berikut:

Tabel 8. Urutan penggunaan fungsi

\begin{tabular}{cccccc}
\hline Proses & \multicolumn{5}{c}{ Ronde } \\
\cline { 2 - 6 } & 1 & 2 & 3 & 4 & 5 \\
\hline Kiri & f1 & f2 & f3 & f4 & f5 \\
Kanan & f5 & f4 & f3 & f2 & f1 \\
\hline
\end{tabular}

3. Konstanta $\mathrm{K}$ 
Nilai Konstanta ditulis dalam bentuk heksadesimal.
$K(j)=00000000_{x}$
$K(j)=5 \mathrm{~A} 827999_{\mathrm{x}}$
$(16 \leq \mathrm{j} \leq 31)$
$K(j)=6$ ED9EBA $1_{x}$
$(32 \leq \mathrm{j} \leq 47)$
$K(j)=8 \mathrm{~F} 1 \mathrm{BBCDC}_{\mathrm{x}}$
$(48 \leq \mathrm{j} \leq 63)$
$K(j)=$ A953FD4 $\mathrm{E}_{\mathrm{x}}$
$(64 \leq \mathrm{j} \leq 79)$
$K^{\prime}(j)=50 \mathrm{~A} 28 \mathrm{BE}_{\mathrm{x}}$
$(0 \leq \mathrm{j} \leq 15)$
$K^{\prime}(j)=5 \mathrm{C} 4 \mathrm{DD} 124_{\mathrm{x}}$
$(16 \leq \mathrm{j} \leq 31)$
$K^{\prime}(j)=6 \mathrm{D} 703 \mathrm{EF} 3_{\mathrm{x}}$
$K^{\prime}(j)=7 \mathrm{~A} 6 \mathrm{D} 76 \mathrm{E} 9_{\mathrm{x}}$
$(32 \leq \mathrm{j} \leq 47)$
$(48 \leq \mathrm{j} \leq 63)$
$K^{\prime}(j)=00000000_{x}$
$(64 \leq \mathrm{j} \leq 79)$

$(0 \leq \mathrm{j} \leq 15)$

Round 1 j(0),r(0),s(0)

B : : 11101111110011011010101110001001

C $\quad$ : 10011000101110101101110011111110

D : : 00010000001100100101010001110110

E : : 11000011110100101110000111110000

A $\quad$ : 01100111010001010010001100000001

$\mathrm{F}(\mathrm{B}, \mathrm{C}, \mathrm{D}) \quad$ :01100111010001010010001100000001

A add mod F(B,C,D) :11001110100010100100011000000010

$\mathrm{X} 0$

:00101111010101110101010001100011

$\mathrm{K}$

:00000000000000000000000000000000

$A$ add $\bmod \mathrm{F}$ (B,C,D add $\bmod \mathrm{X}_{0}$ add $\bmod \mathrm{K}(\mathrm{j})$

$=11111101111000011001101001100101$

$A$ add $\bmod F\left(B, C, D\right.$ add $\bmod X_{0}$ add $\bmod K(\mathrm{j}) \operatorname{rol}_{(0)}$ $=00001100110100110010111111101111$

$\mathrm{A}$ add $\bmod \mathrm{F}\left(\mathrm{B}, \mathrm{C}, \mathrm{D}\right.$ add $\bmod \mathrm{X}_{0}$ add $\bmod \mathrm{K}(\mathrm{j}) \operatorname{rol}_{(0)}$ add $\bmod \mathrm{E}$ $\mathrm{t}=11010000101001100001000111011111$

j(0),r'(0),s'(0)

$\mathrm{B} \quad: 11101111110011011010101110001001$

C $\quad: 10011000101110101101110011111110$

D : : 00010000001100100101010001110110

$\sim \mathrm{D} \quad: 11101111110011011010101110001001$

C v D : 11111111111111111111111111111111

E $\quad: 11000011110100101110000111110000$

Hasil : : 00010000001100100101010001110110

A $\quad: 01100111010001010010001100000001$

$\mathrm{F}(\mathrm{B}, \mathrm{C}, \mathrm{D}) \quad$ : 00010000001100100101010001110110

$\mathrm{A}$ add $\bmod \mathrm{F}(\mathrm{B}, \mathrm{C}, \mathrm{D})=01110111011101110111011101110111$

$\mathrm{X}(0) \quad: 01010111011001010110010101100010$

$\mathrm{K}^{\prime} \quad: 01010000101000101000101111100110$

A add $\bmod F\left(B, C, D\right.$ add $\bmod X(0)$ add $\bmod K^{\prime}(j)$ $=00011111011111110110100010111111$

A add mod F(B,C,D add mod X(0)add mod K'(j) rol $(0)$ $=01111111011010001011111100011111$

A add $\bmod F\left(B, C, D\right.$ add $\bmod X(0)$ add $\bmod K^{\prime}(j) \operatorname{rol}_{(0)}$ add mod $E$ $\mathrm{t}=01000011001110111010000100001111$ Tabel 9. Komputasi Fungsi hash Ripemd160 dalam heksadesimal

\begin{tabular}{|c|c|c|c|c|c|}
\hline$J$ & $\mathrm{~A}$ & $\mathrm{~B}$ & $\mathrm{C}$ & $\mathrm{D}$ & $\mathrm{E}$ \\
\hline $\mathrm{t}(0)$ & 67452301 & EFCDAB89 & 98BADCFE & 10325476 & C3D2E1F0 \\
\hline$t^{\prime}(0)$ & CE5EC8AE & 4C4658F4 & EE6C59E3 & F911BB77 & DA63C751 \\
\hline $\mathrm{t}(1)$ & C3D2E1F0 & A78E06A4 & EFCDAB89 & EB73FA62 & 10325476 \\
\hline$t^{\prime}(1)$ & 7C05842A & EE6C59E3 & DDFE446E & DA63C751 & CE5EC8AE \\
\hline $\mathrm{t}(2)$ & 10325476 & 1E4C7FFF & A78E06A4 & 36AE27BF & EB73FA62 \\
\hline$t^{\prime}(2)$ & FF243AFC & DDFE446E & D47698F1 & CE5EC8AE & 7C05842A \\
\hline $\mathrm{t}(3)$ & EB73FA62 & 1A4AF4E7 & 1E4C7FFF & 381A929E & 36AE27BF \\
\hline$t^{\prime}(3)$ & E0F3835D & D47698F1 & 2BB397B2 & 7C05842A & FF243AFC \\
\hline$t(4)$ & 36AE27BF & 3E91F6FC & 1A4AF4E7 & 31FFFC79 & 381A929E \\
\hline$t^{\prime}(4)$ & 5DD2D91E & 2BB397B2 & A9F0161 & FF243AFC & E0F3835D \\
\hline $\mathrm{t}(5)$ & 381A929E & 1ECBE4F3 & 3E91F6FC & 2BD39C69 & 31FFFC79 \\
\hline$t^{\prime}(5)$ & 60467756 & A9F0161 & BF3FC90E & E0F3835D & 5DD2D91E \\
\hline $\mathrm{t}(6)$ & 31FFFC79 & 3B866314 & 1ECBE4F3 & 47DBF0FA & 2BD39C69 \\
\hline$t^{\prime}(6)$ & $1500 \mathrm{FC} 89$ & BF3FC90E & D7783CE0 & 5DD2D91E & 60467756 \\
\hline $\mathrm{t}(7)$ & 2BD39C69 & 370D676A & 3B866314 & 2F93CC7B & 47DBF0FA \\
\hline
\end{tabular}




\begin{tabular}{|c|c|}
\hline$t^{\prime}(7)$ & 4080A8CF \\
\hline $\mathrm{t}(8)$ & 47DBF0FA \\
\hline$t^{\prime}(8)$ & AEF08C71 \\
\hline $\mathrm{t}(9)$ & 2F93CC7B \\
\hline$t^{\prime}(9)$ & 45999BCE \\
\hline $\mathrm{t}(10)$ & 198C50EE \\
\hline$t^{\prime}(10)$ & 59DFBE70 \\
\hline $\mathrm{t}(11)$ & 359DA8DC \\
\hline$t^{\prime}(11)$ & 538497AC \\
\hline $\mathrm{t}(12)$ & $93365 C 82$ \\
\hline$t^{\prime}(12)$ & 533491A9 \\
\hline $\mathrm{t}(13)$ & B0E76CFB \\
\hline$t^{\prime}(13)$ & 7C49DC03 \\
\hline $\mathrm{t}(14)$ & B6DA90FA \\
\hline$t^{\prime}(14)$ & E24505F9 \\
\hline $\mathrm{t}(15)$ & $625074 \mathrm{FB}$ \\
\hline$t^{\prime}(15)$ & 7F55DB74 \\
\hline $\mathrm{t}(16)$ & C51F0E71 \\
\hline$t^{\prime}(16)$ & 39C087B2 \\
\hline $\mathrm{t}(17)$ & 3D5A926D \\
\hline$t^{\prime}(17)$ & 935EF9A7 \\
\hline $\mathrm{t}(18)$ & 10325476 \\
\hline$t^{\prime}(18)$ & EBBF6BC3 \\
\hline $\mathrm{t}(19)$ & EB73FA62 \\
\hline$t^{\prime}(19)$ & 2A365512 \\
\hline $\mathrm{t}(20)$ & 36AE27BF \\
\hline$t^{\prime}(20)$ & F99C39AE \\
\hline $\mathrm{t}(21)$ & 3EB87414 \\
\hline$t^{\prime}(21)$ & $\mathrm{AC} 12 \mathrm{~F} 410$ \\
\hline $\mathrm{t}(22)$ & $83 B 74976$ \\
\hline$t^{\prime}(22)$ & D8A9D738 \\
\hline $\mathrm{t}(23)$ & C11BCEBB \\
\hline$t^{\prime}(23)$ & 48EB61E8 \\
\hline $\mathrm{t}(24)$ & C70DEE75 \\
\hline$t^{\prime}(24)$ & F3BA533A \\
\hline $\mathrm{t}(25)$ & 5BC251D8 \\
\hline$t^{\prime}(25)$ & 4E1A5B03 \\
\hline $\mathrm{t}(26)$ & ВС6АВ4B4 \\
\hline$t^{\prime}(26)$ & 3A76ADFE \\
\hline $\mathrm{t}(27)$ & E0927785 \\
\hline$t^{\prime}(27)$ & 36AE27BF \\
\hline $\mathrm{t}(28)$ & 7A657850 \\
\hline$t^{\prime}(28)$ & EB73FA62 \\
\hline $\mathrm{t}(29)$ & 22DCF580 \\
\hline$t^{\prime}(29)$ & 10325476 \\
\hline $\mathrm{t}(30)$ & 06ЕC5CAE \\
\hline$t^{\prime}(30)$ & C3D2E1F0 \\
\hline $\mathrm{t}(31)$ & 8ЕECBBC5 \\
\hline$t^{\prime}(31)$ & 67452301 \\
\hline $\mathrm{t}(32)$ & $4616 \mathrm{~F} 2 \mathrm{AC}$ \\
\hline$t^{\prime}(32)$ & 4E5800DF \\
\hline $\mathrm{t}(33)$ & 213008BA \\
\hline$t^{\prime}(33)$ & CC222685 \\
\hline $\mathrm{t}(34)$ & FF2F07A3 \\
\hline$t^{\prime}(34)$ & D5859A9C \\
\hline $\mathrm{t}(35)$ & D96E1BC5 \\
\hline$t^{\prime}(35)$ & B35021A5 \\
\hline $\mathrm{t}(36)$ & 46B51660 \\
\hline$t^{\prime}(36)$ & 5B5D4C01 \\
\hline $\mathrm{t}(37)$ & F00FE10C \\
\hline$t^{\prime}(37)$ & $46 \mathrm{C} 7 \mathrm{~B} 420$ \\
\hline $\mathrm{t}(38)$ & 0945D91B \\
\hline$t^{\prime}(38)$ & 48F06E71 \\
\hline t(39) & 96CA39E5 \\
\hline$t^{\prime}(39)$ & 08BB5CD0 \\
\hline $\mathrm{t}(40)$ & 6B0EEB54 \\
\hline$t^{\prime}(40)$ & В06292B0 \\
\hline $\mathrm{t}(41)$ & 21189DD9 \\
\hline$t^{\prime}(41)$ & 4F48E2E2 \\
\hline $\mathrm{t}(42)$ & BF1EA4AD \\
\hline$t^{\prime}(42)$ & 51D574BE \\
\hline $\mathrm{t}(43)$ & 4FFA93DB \\
\hline$t^{\prime}(43)$ & B73F3097 \\
\hline $\mathrm{t}(44)$ & 96596FDB \\
\hline
\end{tabular}

D7783CE0

20A4CD97

479774B6

3EEC39DB

D598119D

3EADB6A4

2245403F

3ED8941D

33D0202A

9C7147C3

$1 \mathrm{C} 6 \mathrm{BBC} 23$

9B4F56A4

F3916666

E1C3DC85

9C1677EF

BE7B0AD4

EB14E125

EFCDAB89

6A54CD24

050FAE1D

00DF1277

5DA0EDD2

7E789141

AEF046F3

DD1FD576

9D71C37B

EC8E7021

$7616 \mathrm{~F} 094$

69E4D7BE

2D2F1AAD

FOFAEFDA

E178249D

448A8D95

141E995E

6BBE670E

6008B73D

42B04BD

2B81BB17

CE362A75

F163BB2E

7A123AD8

AB 1185BC

CEBCEE94

2E884C02

C0D38696

E8FFCBC1

7F8E9DAB

78BB2DC3

EFCDAB89

9811AD45

A1E994BC

433C03F8

6F6D6B06

$46 \mathrm{C} 25176$

BD47E0B7

7965B28E

9C1C93C9

D51AC3BA

37D39600

76484627

A 1730889

2B6FC7A9

A7356166

F6D3FEA4

696CD408

F6E5965B

$0056 \mathrm{D} 753$

0E6839EA

811B1ED

3292547D

$9 \mathrm{C} 523 \mathrm{C} 1 \mathrm{~B}$

$23 \mathrm{C} 58 \mathrm{C} 3 \mathrm{E}$

34022ED7

93183775

AC2C18A4
370D676A

D598119D

20A4CD97

$2245403 \mathrm{~F}$

3EEC39DB

33D0202A

3EADB6A4

$1 \mathrm{C} 6 \mathrm{BBC} 23$

3ED8941D

F3916666

9C7147C3

9C1677EF

9B4F56A4

EB14E125

E1C3DC85

6A54CD24

BE7B0AD4

00DF1277

EFCDAB89

7E789141

050FAE1D

DD1FD576

5DA0EDD2

EC8E702

AEF046F3

69E4D7BE

9D71C37B

FOFAEFDA

7616F094

448A8D95

2D2F1AAD

6BBE670E

E178249D

42B04BD

141E995E

CE362A75

6008B73D

7A123AD8

2B81BB 17

CEBCEE94

F163BB2E

C0D38696

AB 1185BC

7F8E9DAB

2E884C02

EFCDAB89

E8FFCBC1

98BADCFE

78BB2DC3

6F6D6B06

9811AD45

BD47E0B7

433C03F8

9C1C93C9

46C25176

37D39600

7965B28E

A1730889

D51AC3BA

A7356166

76484627

696CD408

2B6FC7A9

0056D753

F6D3FEA4

0811B1ED

F6E5965B

9C523C1B

0E6839EA

34022ED7

3292547D

AC2C18A4

23C58C 3E

B893D238
60467756

198C50EE

$1500 \mathrm{FC} 89$

359DA8DC

4080A8CF

93365C 82

AEF08C71

B0E76CFB

45999BCE

B6DA90FA

59DFBE70

625074FB

538497AC

C51F0E71

533491A9

3D5A926D

7C49DC03

10325476

E24505F9

EB73FA62

7F55DB74

36AE27BF

39C087B2

3EB87414

935EF9A7

83B74976

EBBF6BC3

C11BCEBB

2A365512

C70DEE75

F99C39AE

5BC251D8

AC12F410

BC6AB4B4

D8A9D738

E0927785

48EB61E8

7A657850

F3BA533A

22DCF580

4E1A5B03

06EC5CAE

3A76ADFE

8 EECBBC 5

36AE27BF

4616F2AC

EB73FA62

213008BA

10325476

FF2F07A3

1F82DEF5

D96E1BC5

724F2670

46B51660

4E5800DF

F00FE10C

CC222685

0945D91B

D5859A9C

96CA39E5

B35021A5

6B0EEB54

5B5D4C01

21189DD9

46C7B420

BF1EA4AD

48F06E71

4FFA93DB

8BB5CD0

96596FDB

B06292B0

D073D41C

4F48E2E2

4951F4CA

51D574BE

1500FC 89

2F93CC7B

4080A8CF

198C50EE

AEF08C71

359DA8DC

45999BCE

93365C82

59DFBE70

B0E76CFB

538497AC

B6DA90FA

533491A9

625074FB

7C49DC03

C51F0E71

E24505F9

3D5A926D

7F55DB74

10325476

39C087B2

EB73FA62

935EF9A7

36AE27BF

EBBF6BC3

3EB87414

2A365512

83B74976

F99C39AE

C11BCEBB

AC12F410

C70DEE75

D8A9D738

5BC251D8

48EB61E8

BC6AB4B4

F3BA533A

E0927785

4E1A5B03

7A657850

3A76ADFE

22DCF580

36AE27BF

06EC5CAE

EB73FA62

8 EECBBC5

10325476

4616F2AC

C3D2E1F0

213008BA

724F2670

FF2F07A3

4E5800DF

D96E1BC5

CC222685

46B51660

D5859A9C

F00FE10C

B35021A5

0945D91B 


\begin{tabular}{|c|c|c|c|c|c|}
\hline $\mathrm{t}(45)$ & D073D41C & 444FAB8F & 93183775 & $1630 \mathrm{~F} 88 \mathrm{~F}$ & 4951F4CA \\
\hline$t^{\prime}(45)$ & AD514ED1 & B893D238 & 2F94755D & B73F3097 & 498DA5BF \\
\hline $\mathrm{t}(46)$ & 4951F4CA & 167DD06C & 444FAB $8 F$ & 60DDD64C & $1630 \mathrm{~F} 88 \mathrm{~F}$ \\
\hline$t^{\prime}(46)$ & $53250 \mathrm{FF} 1$ & 2F94755D & 25EDCFCC & 498DA5BF & AD514ED1 \\
\hline $\mathrm{t}(47)$ & $1630 \mathrm{~F} 88 \mathrm{~F}$ & 6ED4F786 & 167DD06C & 3EAE3D11 & 60DDD64C \\
\hline$t^{\prime}(47)$ & 304166E8 & 25EDCFCC & 6FD26369 & AD514ED1 & $53250 \mathrm{FF} 1$ \\
\hline $\mathrm{t}(48)$ & 60DDD64C & 3152AD16 & 6ED4F786 & F741B059 & 3EAE3D11 \\
\hline$t^{\prime}(48)$ & 839AE6B3 & 6FD26369 & B46B5453 & $53250 \mathrm{FF} 1$ & 304166E8 \\
\hline $\mathrm{t}(49)$ & 3EAE3D11 & D4EE8A39 & 3152AD16 & 53DE19BB & F741B059 \\
\hline$t^{\prime}(49)$ & $11 \mathrm{CF} 7609$ & B46B5453 & FC54C 943 & $304166 \mathrm{E} 8$ & 839AE6B3 \\
\hline $\mathrm{t}(50)$ & F741B059 & $81 \mathrm{~A} 45442$ & D4EE8A39 & $4 \mathrm{AB} 458 \mathrm{C} 5$ & 53DE19BB \\
\hline$t^{\prime}(50)$ & A832A3C 8 & FC54C943 & ВА0C 1059 & 839AE6B3 & 11CF7609 \\
\hline $\mathrm{t}(51)$ & 53DE19BB & $63 \mathrm{C} 9608 \mathrm{E}$ & $81 \mathrm{~A} 45442$ & BA28E753 & $4 \mathrm{AB} 458 \mathrm{C} 5$ \\
\hline$t^{\prime}(51)$ & $7173 \mathrm{C} 247$ & BA0C 1059 & ACE0E6B9 & 11CF7609 & A832A3C 8 \\
\hline $\mathrm{t}(52)$ & $4 \mathrm{AB} 458 \mathrm{C} 5$ & 6E00DC08 & $63 \mathrm{C} 9608 \mathrm{E}$ & 91510A06 & BA28E753 \\
\hline$t^{\prime}(52)$ & 1DDE6CDB & ACE0E6B9 & 824473DD & A 832 A 3 C 8 & $7173 \mathrm{C} 247$ \\
\hline $\mathrm{t}(53)$ & BA28E753 & AECC023E & 6E00DC08 & $2582398 \mathrm{~F}$ & 91510A06 \\
\hline$t^{\prime}(53)$ & BF52D016 & 824473DD & F22A0CA8 & $7173 C 247$ & 1DDE6CDB \\
\hline $\mathrm{t}(54)$ & 91510A06 & 456FE5E8 & AECC023E & 037021B8 & $2582398 \mathrm{~F}$ \\
\hline$t^{\prime}(54)$ & A32DF4B3 & F22A0CA8 & 91DC5CF0 & 1DDE6CDB & BF52D016 \\
\hline $\mathrm{t}(55)$ & $2582398 \mathrm{~F}$ & 17140B28 & 456FE5E8 & 3008FABB & 037021B8 \\
\hline$t^{\prime}(55)$ & 877AAF72 & 91DC5CF0 & $36 \mathrm{C} 7779 \mathrm{~B}$ & BF52D016 & A32DF4B3 \\
\hline$t(56)$ & 037021B8 & 6FB9E620 & 17140B28 & BF97A115 & 3008FABB \\
\hline$t^{\prime}(56)$ & 2CEC067A & $36 \mathrm{C} 7779 \mathrm{~B}$ & 5AFD4B4 & A32DF4B3 & 877AAF72 \\
\hline $\mathrm{t}(57)$ & 3008FABB & $6 \mathrm{~B} 1 \mathrm{~A} 743 \mathrm{~F}$ & 6FB9E620 & 502CA05C & BF97A115 \\
\hline$t^{\prime}(57)$ & 66E6F2F5 & 5AFD4B4 & 2CE8CB7D & 877AAF72 & 2CEC067A \\
\hline $\mathrm{t}(58)$ & BF97A115 & $61 \mathrm{~A} 1815 \mathrm{~A}$ & $6 \mathrm{~B} 1 \mathrm{~A} 743 \mathrm{~F}$ & E79881BE & $502 \mathrm{CA} 05 \mathrm{C}$ \\
\hline$t^{\prime}(58)$ & $66671 \mathrm{CC} 4$ & 2CE8CB7D & DCA1DEAB & 2CEC067A & 66E6F2F5 \\
\hline $\mathrm{t}(59)$ & $502 \mathrm{CA} 05 \mathrm{C}$ & 56F701F3 & $61 \mathrm{~A} 1815 \mathrm{~A}$ & 69D0FDAC & E79881BE \\
\hline$t^{\prime}(59)$ & 834D66F2 & DCA1DEAB & 9E8B3B01 & 66E6F2F5 & $66671 \mathrm{CC} 4$ \\
\hline $\mathrm{t}(60)$ & E79881BE & F5F07E46 & $56 \mathrm{~F} 701 \mathrm{~F} 3$ & 86056986 & 69D0FDAC \\
\hline$t^{\prime}(60)$ & CCB64CC7 & 9E8B3B01 & BD59B9BC & $66671 \mathrm{CC} 4$ & 834D66F2 \\
\hline $\mathrm{t}(61)$ & 69D0FDAC & 10780EF7 & F5F07E46 & DC07CD5B & 86056986 \\
\hline$t^{\prime}(61)$ & 7C75AE7C & BD59B9BC & $311999 \mathrm{C} 7$ & 834D66F2 & CCB64CC7 \\
\hline $\mathrm{t}(62)$ & 86056986 & 169CF9E6 & 10780EF7 & C1F91BD7 & DC07CD5B \\
\hline$t^{\prime}(62)$ & CDA39A1D & $311999 \mathrm{C7}$ & BCA0D359 & CCB64CC7 & 7C75AE7C \\
\hline $\mathrm{t}(63)$ & DC07CD5B & $4330566 \mathrm{D}$ & 169CF9E6 & E03BDC41 & C1F91BD7 \\
\hline$t^{\prime}(63)$ & 12379963 & BCA0D359 & 31F32D93 & 7C75AE7C & CDA39A1D \\
\hline $\mathrm{t}(64)$ & C1F91BD7 & FCA02D4B & $4330566 \mathrm{D}$ & 73E7985A & E03BDC41 \\
\hline$t^{\prime}(64)$ & FB5AC889 & 31F32D93 & 9F1F1D6B & CDA39A1D & 12379963 \\
\hline $\mathrm{t}(65)$ & E03BDC41 & 4F7A08F6 & FCA02D4B & C159B50C & 73E7985A \\
\hline$t^{\prime}(65)$ & DC43FFB7 & 9F1F1D6B & 877368E6 & 12379963 & FB5AC889 \\
\hline $\mathrm{t}(66)$ & 73E7985A & 35E58D33 & 4F7A08F6 & C159B50C & C159B50C \\
\hline$t^{\prime}(66)$ & 4A99A876 & 877368E6 & 58C48DE6 & FB5AC889 & DC43FFB7 \\
\hline $\mathrm{t}(67)$ & C159B50C & 98F20EE3 & 35E58D33 & E823D93D & C159B50C \\
\hline$t^{\prime}(67)$ & 21C5DA99 & 58C48DE6 & 227ED6B2 & DC43FFB7 & 4A99A876 \\
\hline $\mathrm{t}(68)$ & C159B50C & ABF505D9 & 98F20EE3 & 9634CCD7 & E823D93D \\
\hline$t^{\prime}(68)$ & 397AD $2 A 3$ & 227ED6B2 & EDF710FF & 4A99A876 & 21C5DA99 \\
\hline $\mathrm{t}(69)$ & E823D93D & 171EFC6C & ABF505D9 & C83B8E63 & 9634CCD7 \\
\hline$t^{\prime}(69)$ & 8CF8C08D & EDF710FF & 1D92A66A & 21C5DA99 & 397AD $2 A 3$ \\
\hline $\mathrm{t}(70)$ & 9634CCD7 & F9950911 & 171EFC6C & D41766AF & C83B8E63 \\
\hline$t^{\prime}(70)$ & 2B3F95A6 & 1D92A66A & A6487176 & 397AD 2 A 3 & 8CF8C08D \\
\hline $\mathrm{t}(71)$ & C83B8E63 & D55839CF & F9950911 & 7BF1B05C & D41766AF \\
\hline$t^{\prime}(71)$ & DBBB0BBB & A6487176 & A8CE5EB4 & 8CF8C08D & 2B3F95A6 \\
\hline$t(72)$ & D41766AF & $443 \mathrm{~A} 4054$ & D55839CF & $542447 \mathrm{E} 6$ & 7BF1B05C \\
\hline$t^{\prime}(72)$ & CB225A09 & A8CE5EB4 & 23633E30 & 2B3F95A6 & DBBB0BBB \\
\hline $\mathrm{t}(73)$ & 7BF1B05C & A59D6163 & 443A4054 & 60E73F55 & 542447E6 \\
\hline$t^{\prime}(73)$ & AC98639C & 23633E30 & 2B3F95A6 & DBBB0BBB & CB225A09 \\
\hline $\mathrm{t}(74)$ & 542447E6 & 6DED6999 & A59D6163 & E9015110 & 60E73F55 \\
\hline$t^{\prime}(74)$ & EE843D0C & 2B3F95A6 & EEF6EEC2 & CB225A09 & AC98639C \\
\hline $\mathrm{t}(75)$ & 60E73F55 & C7A70491 & 6DED6999 & $75858 \mathrm{E} 96$ & E9015110 \\
\hline$t^{\prime}(75)$ & 36AE27BF & EEF6EEC2 & $8272 C 896$ & AC98639C & EE843D0C \\
\hline $\mathrm{t}(76)$ & E9015110 & D7841DB4 & C7A70491 & B5A665B7 & $75858 \mathrm{E} 96$ \\
\hline$t^{\prime}(76)$ & EB73FA62 & $8272 C 896$ & E72B2618 & EE843D0C & 36AE27BF \\
\hline $\mathrm{t}(77)$ & $75858 \mathrm{E} 96$ & FC13EBEC & D7841DB4 & $9 \mathrm{C} 12471 \mathrm{E}$ & B5A665B7 \\
\hline$t^{\prime}(77)$ & 10325476 & E72B2618 & 433BA $10 \mathrm{~F}$ & 36AE27BF & EB73FA62 \\
\hline $\mathrm{t}(78)$ & B5A665B7 & D88634F & FC13EBEC & 1076D35E & $9 \mathrm{C} 12471 \mathrm{E}$ \\
\hline$t^{\prime}(78)$ & C3D2E1F0 & 433BA10F & EFCDAB89 & EB73FA62 & 10325476 \\
\hline $\mathrm{t}(79)$ & $9 \mathrm{C} 12471 \mathrm{E}$ & BDD05508 & D88634F & 4FAFB3F0 & 1076D35E \\
\hline$t^{\prime}(79)$ & 67452301 & EFCDAB89 & 98BADCFE & 10325476 & C3D2E1F0 \\
\hline
\end{tabular}

\section{IMPLEMENTASI}

Adapun hasil implementasi sebagai berikut: 


\begin{tabular}{|c|c|c|c|c|c|}
\hline Parameter & Citra Awal & Citra Manipulasi & $\begin{array}{l}\text { Nilai Hash } \\
\text { Citra Awal }\end{array}$ & $\begin{array}{c}\text { Nilai Hash Citra } \\
\text { Manipulasi }\end{array}$ & Hasil \\
\hline $\begin{array}{l}\text { Mengubah } \\
\text { resolusi citra } \\
\text { sertifikat tanah }\end{array}$ & & 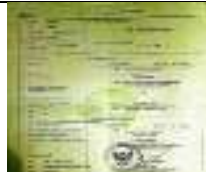 & $\begin{array}{l}8 \mathrm{ae} 1 \mathrm{fe} 38 \\
488640 \mathrm{a} 3 \\
20 \mathrm{c} 9 \mathrm{a} 068 \\
\text { f764f8c9 } \\
97 \mathrm{ea} 0 \mathrm{cb} 4\end{array}$ & $\begin{array}{l}06654 \mathrm{fd} 8 \\
\text { af48daf1 } \\
7 \mathrm{ad} 8869 \mathrm{e} \\
\text { fa55891a } \\
40381 \mathrm{c} 8 \mathrm{f}\end{array}$ & Terdeteksi \\
\hline $\begin{array}{l}\text { Mengubah nilai } \\
\text { satu piksel citra } \\
\text { sertifikat tanah }\end{array}$ & & $t=2=$ & $\begin{array}{l}8 \mathrm{ae} 1 \mathrm{fe} 38 \\
488640 \mathrm{a} 3 \\
20 \mathrm{c} 9 \mathrm{a} 068 \\
\text { f764f8c9 } \\
97 \mathrm{ea} 0 \mathrm{cb} 4\end{array}$ & $\begin{array}{l}\text { 7be6f7a1 } \\
81923324 \\
173579 \mathrm{~b} 5 \\
\text { 4d83f51e } \\
1 \mathrm{~d} 80 \mathrm{f} 492\end{array}$ & Terdeteksi \\
\hline $\begin{array}{l}\text { Mengubah nilai } \\
\text { kontras citra } \\
\text { sertifikat tanah }\end{array}$ & $=69$ & & $\begin{array}{l}8 \mathrm{ae} 1 \mathrm{fe} 38 \\
488640 \mathrm{a} 3 \\
20 \mathrm{c} 9 \mathrm{a} 068 \\
\text { f764f8c9 } \\
97 \mathrm{ea0cb} 4\end{array}$ & $\begin{array}{l}\text { d304679d } \\
d 9 c b a 2 f a \\
b c 3018 a 2 \\
b d 610 b f 3 \\
1 c 035401\end{array}$ & Terdeteksi \\
\hline $\begin{array}{l}\text { Mengubah satu } \\
\text { karakter citra } \\
\text { sertifikat tanah }\end{array}$ & $\equiv 9 g_{2}$ & $1:=92$ & $\begin{array}{l}8 \mathrm{ae} 1 \mathrm{fe} 38 \\
488640 \mathrm{a} 3 \\
20 \mathrm{c} 9 \mathrm{a} 068 \\
\text { f764f8c9 } \\
97 \mathrm{ea} 0 \mathrm{cb} 4\end{array}$ & $\begin{array}{l}\text { cccf618e } \\
5 \mathrm{bc} 8 \mathrm{c} 8 \mathrm{f} 5 \\
300 \mathrm{cddfa} \\
3121124 \mathrm{~b} \\
\text { fe } 10584 \mathrm{~d}\end{array}$ & Terdeteksi \\
\hline
\end{tabular}

\section{KESIMPULAN}

Adapun kesimpulan yang dapat diambil setelah penelitian ini dilakukan akan diurakan sebagai berikut :

1. Algoritma RIPEMD160 dapat digunakan untuk mendeteksi keaslian citra digital sertifikat tanah.

2. Algoritma RIPEMD160 dapat mendeteksi perubahan sekecil apapun dari citra awal dan citra manipulasi, yang dapat dilihat dari perbedaan nilai hashnya.

\section{REFERENCES}

[1] H. Eka, "Analisis dan Penerapan Algoritma RIPEMD-160 Sebagai Fungsi Penyandi Dalam Proses Autentifikasi Password."

[2] F.Mulia, "STUDI,_ANALISIS,_DAN_IMPLEMENTASI_FUNGSI_HASH_RIPEMD_PDF.pdf."

[3] Dony Ariyus, Pengantar Ilmu Kriptografi Teori Analisis dan Implementasi, 1st ed. Yogyakarta: Andi, 2008.

[4] H. Mukhtar, Kriptografi untuk Keamanan Data. CV.BUDI UTAMA, 2018.

[5] R. Sadikin, Kriptografi Untuk Keamanan Jaringan, 1st ed. Yogyakarta: Andi, 2012.

[6] "Studi Model Algoritma Kriptografi Klasik dan Modern," Semin. Mat. dan Pendidik. Mat. UNY, pp. 265-272, 2017.

[7] Rinaldi Munir, Pengolahan Citra Digital dengan Pendekatan Algoritmik. Bandung, 2007. 